\title{
Genetic Diversity Analysis of the Natural Populations of Mediterra- nean Mussels [Mytilus galloprovincialis (Lmk.)] in Agadir Bay: Assess- ment of the Molecular Polymorphism and Environmental Impact
}

\author{
Amal Korrida ${ }^{1,2}$, , Sami Jamil Jadallah', Hassan Izaabel', and Said Benhissoune ${ }^{3}$
}

'Equipe de Génétique et Ecologie des Populations Humaines (GEPH), Laboratoire de Biologie Cellulaire et Génétique Moléculaire (LBCGM), Université Ibn Zohr, Faculté des Sciences Agadir, BP 8106 Cité Dakhla, Agadir, Morocco. ${ }^{2}$ HRH Prince Sultan Bin Abdul Aziz Al Saud International Foundation for Conservation \& Development of Wildlife, Department of Genetics, PO Box 116, Agadir, Morocco. ${ }^{3}$ Laboratoire des Substances Naturelles. Equipe d'Océanographie Biologique, Département de Biologie, Université lbn Zohr, Faculté des Sciences Agadir, BP 403, Agadir, Morocco.

Received: February 16, 2010 / Accepted: May 20, 2010

Absract

$M$ editerranean mussel (Mytilus galloprovincialis Lmk) has a great environmental and economic importance for Morocco. This work studies the genetic structure and impact of chemical pollution on three different marine populations of Mytilus galloprovincialis that live within Agadir bay. Three collections were made at two clean sites (Cape Ghir and Cape Aglou) and at an impacted site exposed to intense boating and industrial activities (Anza). A 300-bp portion of the mitochondrial DNA coding-region Cytochrome C Oxidase subunit 1 (COI) was studied by polymerase chain reaction (PCR) and DNA sequencing reactions to assess and evaluate amounts of polymorphism in each site. Genetic analysis using $\mathrm{COI}$ for $\mathbf{6 4}$ individuals showed no significant differentiation between the three subpopulations. AMOVA demonstrated that only $2.83 \%$ of variation exists between populations. Besides the genetic evidence presented herein, mussel's adaptation mechanisms and strategies to marine pollution are also discussed.

Key words: Mytilus galloprovincialis, Cytochrome C Oxidase gene, marine pollution, mussels' genetic structure.

*Corresponding author: amalkorrida11@aol.com

\section{Introduction}

Mytilus galloprovincialis is a cosmopolitan and an invasive species with antitropical distribution that occurs in the Atlantic coasts from Agadir bay to the British Isles, the whole Mediterranean basin, South Africa, New Zealand and California. (McDonald et al. 1991 and Naciri 1998). In the Northern Hemisphere, $M$. edulis constitutes a complex comprising three species: M. galloprovincialis, $M$. edulis and $M$. trossulus. Genetic studies on mussels using morphometric characters, allozymes and the mitochondrial 16S rDNA gene (McDonald et al.1991 and Hilbish et al. 2000) suggested that in the Southern Hemisphere, mussels are in general closely related to $M$. galloprovincialis, except for Mytilus spp. from Kerguelen Islands and South America that might be related to $M$. edulis (Gérard et al. 2008).

The taxonomic status of the genus Mytilus is still unclear and in Morocco, where hybridization is the most likely common, at least four species belonging to the family Mytilidae can be found: Perna perna (Abouabdellah et al. 2008), Mytilus galloprovincialis (Daguin et al. 1999 and Kaimoussi et al. 2001), Mytilus edulis (Dardignac-Corbeil 1986), and Perna picta (Shafee et al. 1989 and Wood et al. 2007). The coastal and marine environment of Agadir bay, which stretches for about $8 \mathrm{~km}$, is exposed to intensive urban rejections at Anza area, as a consequence of industrial, agricultural, and boating activities that characterise this area. The majority of pollutants are directly discharged in 
the Atlantic Ocean with no preliminary treatment. We chose to work on the Mediterranean mussel species for several reasons: (i) it has social, economic and ecological interest (ii) as a sentinel species, sensitive to xenobiotic substances and bio-accumulating marine pollutants, it constitutes a good indicator of water quality (iii) its sampling is straightforward, especially during low-tide periods (iv) except for the studies done by (Jaziri et al. 2002 and 2003), the genetics of mytilids is not well-studied in Morocco, whereas their biology, population dynamics and ecology is much better known (Bouhaimi et al. 1999-2000, Mimouni et al. 2002, Moustaid et al. 2005, Maanan et al. 2008).

We examined a part of the mitochondrial DNA (mtDNA) Cytochrom $C$ Oxidase subunit I (COI) to study the genetic structure of Mytilus galloprovincialis species and to assess the impact of pollution or environmental contamination on this important component of the Moroccan marine community.

\section{Materials and Methods}

\section{Study Sites and Sample Collection}

Three stations on the Atlantic coast of Morocco were the subject of this environmental and genetic study: (a) Cape Ghir station $\left(30^{\circ} 38 \mathrm{~N}\right.$ and $9^{\circ} 53 \mathrm{~W}$ ) is situated $50 \mathrm{~km}$ north of Agadir City. This clean area with an important ecological interest is considered as the southern limit of the coastal Upwelling (Benomar et al. 2006). In April 2008, 16 females were collected and a seawater $\mathrm{pH}$ of 7.7 was measured, (b) Anza station $\left(30^{\circ} 26 \mathrm{~N}\right.$ and $9^{\circ} 38 \mathrm{~W}$ ) is located $8 \mathrm{~km}$ north of Agadir City. This site is exposed to intensive boating and industrial activities and is classified as polluted (trace metals, inorganic elements, polycyclic aromatic hydrocarbons ...etc.) (Mimouni et al. 2002). A total of 32 individuals were sampled in June 2008. The seawater $\mathrm{pH}$ was 7.2, and (c) Cape Aglou site $\left(29^{\circ} 48 \mathrm{~N}\right.$ and $\left.9^{\circ} 49 \mathrm{~W}\right)$ is approximately $100 \mathrm{~km}$ south of Agadir City at the foot of the Anti-Atlas Mountains. In April 2008, a total of 16 females were collected from Afetass Aglou village. The seawater $\mathrm{pH}$ was 8.8. The whole sampling process was carried out during the low-tide periods and all samples were put on ice during their transportation to the laboratory, and then stored at $-20^{\circ} \mathrm{C}$.

\section{DNA Extraction, Primers Design, Amplification and Sequencing}

Genomic DNA was extracted from the adductor muscle using phenol-chloroform (Sambrook et al. 1989) and Chelex-100 methods. A part of the mitochondrial COI gene (300 bp) were amplified using (Folmer et al. 1994) primers, which we modified and re-designed in this study: LCOI1490-M13F: 5-AGG GTT TTC CCA GTC ACG ACG TTG GTC AAC AAA TCA TAA AGA TAT TGG-3'and HCO2198-M13R: 5'-GAG CGG ATA ACA ATT TCA CAC AGG TAA ACT TCA GGG TGA CCA AAA AAT CA-3'. Gradient PCRs were used during the optimisation phase and for a final volume of $20 \mu \mathrm{l}$. The PCR master mix contained $1.5 \mu \mathrm{l}$ of ADN, $10 \mu \mathrm{M}$ of dNTPs, $2.5 \mu \mathrm{M}$ of $\mathrm{MgCl} 2,0.5 \mu \mathrm{M}$ of forward and reverse primers, 0.0375 units of Taq Polymerase and $10.75 \mu \mathrm{l}$ of MilliQ H2O. PCR reactions were carried out using a Biometra $T 1$ thermal cycler under the following conditions: one cycle at $94^{\circ} \mathrm{C}$ for $4 \mathrm{~min}, 30$ cycles at $94^{\circ} \mathrm{C}$ for $15 \mathrm{~s}, 60^{\circ} \mathrm{C}$ for $30 \mathrm{~s}$ and $72{ }^{\circ} \mathrm{C}$ for $30 \mathrm{~s}$, and one final cycle at $72^{\circ} \mathrm{C}$ for $10 \mathrm{~min} . \mathrm{PCR}$ products were loaded in a $1 \%$ low melting point agarose gel and visualised under UV light. Using a sterile scalpel, the bands of interest were cut from the agarose gel and purified using the traditional Freeze-Squeeze method (Diethard \& Renz 1983). $8.15 \mu \mathrm{l}$ of each purified PCR product were then used as a template for bidirectional sequencing using the fmol ${ }^{\circledR}$ DNA cycle sequencing system (Promega). The same PCR profile was used as described above except for the addition of $10 \%$ DMSO as an adjuvant. Sequencing PCR products were electrophoresed on a Li-COR $4000 \mathrm{~L}$ sequencing device with a $6.5 \%$ Li-COR KB Plus Gel Matrix.

\section{Data Analysis}

Sequences were aligned and edited using the software Proseq v 2.91 (Filatov D.A 2002). TCS Software (Clement et al. 2000) was used to infer the genealogical relationships among haplotypes of the 3 populations and the construction of the Minimum spanning network. Analysis of Molecular Variance (AMO$\mathrm{VA})$, genetic variance partitioning among and within populations, pairwise Fst and P-value, and the assessment of the gene flow amount were carried out using Arlequin package (Excoffier et al. 2006). The distance method considered was the Kimura 2-parameters (1980). Neutrality tests, haplotype and nucleotide diversities, genetic code assignment, DNA polymorphism, and divergence were estimated using DnaSP v. 5.10.01 (Librado and Rozas 2009).

\section{Results}

\section{Intra-population Variation}

A total of $300 \mathrm{bp}$ of M. galloprovincialis' COI was successfully sequenced and generated 13 haplotypes $(8$ hplotypes in Anza site with 3 shared and 5 private, 4 haplotypes in Aglou site with 3 shared and 1 private and 6 in Cape Ghir site with 2 shared and 4 private). The haplotypes distribution within the whole population of mussels is given in (Table 3 ). Were carried out also, 10 segregating or polymorphic sites with 5 in Anza site at nucleotide positions (109, 112, 224, 235, and 265), 5

Table 1. DNA sequences variation of the 13 observed haplotypes in the three populations of Mytilus galloprovincialis at Agadir bay.

\begin{tabular}{lcccccccccc}
\hline Haplotypes & 6 & 54 & 88 & 109 & 112 & 170 & 224 & 235 & 265 & 270 \\
Hap 1 (Anza 1) & A & T & T & T & C & T & C & T & T & C \\
Hap 2 (C.Ghir 26) &. & C &. &. &. & A &. &. &. &. \\
Hap 3 (C.Ghir 13) &. &. & C &. &. &. &. &. & C &. \\
Hap 4 (Anza 32) &. &. &. & C & T &. &. &. &. &. \\
Hap 5 (Anza 19) &. &. &. &. & T &. &. & C &. &. \\
Hap 6 (Anza 21) &. &. &. &. & T &. &. &. &. &. \\
Hap 7 (Anza 31) &. &. &. &. & T &. & T &. &. &. \\
Hap 8 (Anza 30) &. &. &. &. &. &. & T & C & C &. \\
Hap 9 (Anza 14) &. &. &. &. &. &. &. & C & C &. \\
Hap 10 (C.Ghir 28) &. &. &. &. &. &. &. &. &. & A \\
Hap 11 (Anza 4) &. &. &. &. &. &. &. & C &. &. \\
Hap 12 (C.Ghir 14) &. &. &. &. &. &. & T &. &. &. \\
Hap 13 (C.Aglou 11) & C & C &. &. &. &. &. &. & C &. \\
\hline
\end{tabular}


Table 2. Summary of the DNA polymorphism inferred from $64 \mathrm{mtDNA}$ sequences of M. galloprovicialis in Agadir Bay.

\begin{tabular}{llllll}
\hline Study Sites & $n$ & No. of Segregating Sites & No. of Haplotypes & $h$ & $\pi$ \\
\hline Anza & 32 & 5 & 8 & $0.8044 \pm 0.0431$ & $0.0043 \pm 0.0031$ \\
Cape Aglou & 16 & 5 & 4 & $0.6750 \pm 0.0853$ & $0.0035 \pm 0.0027$ \\
Cape Ghir & 16 & 7 & 6 & $0.7667 \pm 0.0839$ & $0.0042 \pm 0.0031$ \\
\hline
\end{tabular}

(h): Gene or haplotype diversity \pm standard deviation

$(\pi)$ : Nucleotide diversity \pm standard deviation.

Table 3. Haplotype distribution in the Mediterranean mussel among the three study sites.

\begin{tabular}{lccc}
\hline Haplotype & Anza (32) & C. Aglou (16) & C. Ghir (16) \\
\hline Hap 1 & 11 & 8 & 7 \\
Hap4 & 1 & 0 & 0 \\
Hap6 & 5 & 2 & 0 \\
Hap7 & 1 & 0 & 0 \\
Hap8 & 1 & 0 & 0 \\
Hap9 & 2 & 0 & 0 \\
Hap5 & 3 & 0 & 0 \\
Hap 1 1 & 8 & 5 & 4 \\
Hap 1 3 & 0 & 1 & 0 \\
Hap 2 & 0 & 0 & 1 \\
Hap3 & 0 & 0 & 1 \\
Hap 1 0 & 0 & 0 & 1 \\
Hap 1 2 & 0 & 0 & 2 \\
\hline
\end{tabular}

Table 4. Estimates of pairwise P-value (above the diagonal) and Fst (below the diagonal) for the three populations of the Mediterranean mussel. * $P<0.05$.

\begin{tabular}{lccc}
\hline & Anza & C. Aglou & C. Ghir \\
\hline Anza & - & 0.33496 & $0.02637^{*}$ \\
C. Aglou & 0.00562 & - & 0.70801 \\
C. Ghir & $0.06792^{*}$ & -0.01922 & - \\
\hline
\end{tabular}

Table 5. Analysis of Molecular Variance (AMOVA) at the inter- and intra-population levels.

\begin{tabular}{lcccc}
\hline Source of Variation & $\begin{array}{c}\text { Degrees of } \\
\text { freedom }\end{array}$ & $\begin{array}{c}\text { Sum of } \\
\text { squares }\end{array}$ & $\begin{array}{c}\text { Variatio } \\
\mathbf{n}\end{array}$ & $\begin{array}{c}\% \text { of } \\
\text { variation }\end{array}$ \\
\hline Among populations & 2 & 1.972 & 0.01816 & 2.83 \\
Within populations & 61 & 37.993 & 0.62283 & 97.17 \\
Total & 63 & 39.964 & 0.64098 & 100 \\
\hline
\end{tabular}

in Aglou site at positions (6,54, 112, 235, and 265), and 7 in Cape Ghir at positions $(54,88,170,224,235,265$, and 270 ) (Table 1 and 2). The nucleotide and protein sequences of the 13 haplotypes were deposited in GenBank under accession numbers FJ638333, FJ638334, FJ638335, FJ638336, FJ638337, FJ638338, FJ638339, FJ638340, FJ638341, FJ638342, FJ638343, FJ638344, and FJ172994. The genetic code was first assigned assuming the invertebrates mitochondrial code as described by (Hoffmann et al. 1992) in Mytilus. Five parcimony sites $(54,112,224,235$, and 265), six sites with synonymous or silent substitutions $(88,109,112,224,235$, and 265$)$ and four

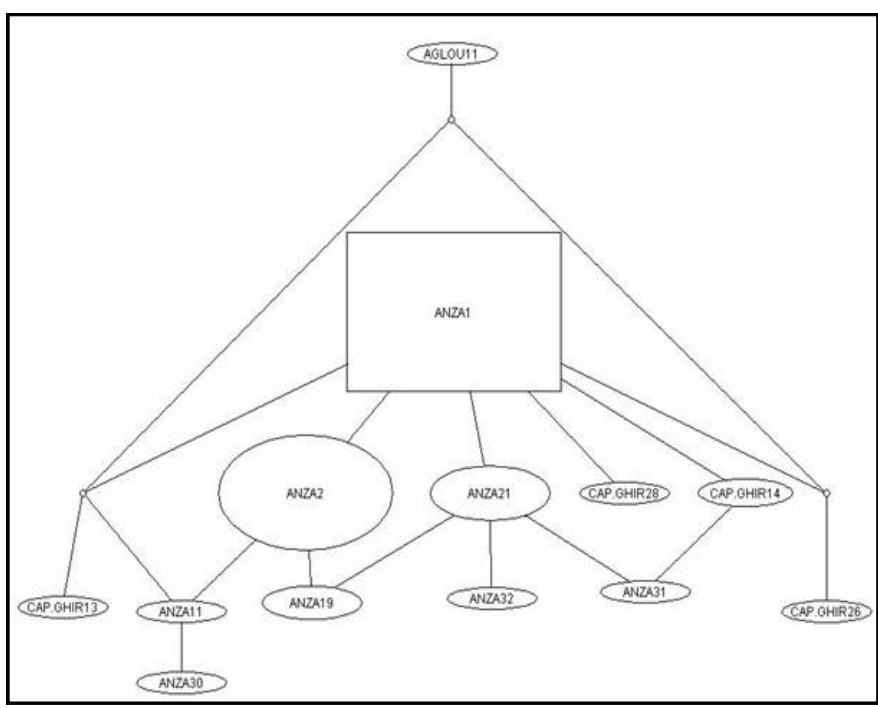

Figure 1. Minimum spanning network constructed from the $300 \mathrm{bp}$ sequences of the mtDNA Cytochrome $C$ oxidase gene.

sites with non-synonymous substitutions or amino acid altering mutations $(6,54,170,270)$ were determined at the first and/or the second position of codons (Table 1). The 4 latter substitutions changed the amino acid sequences of the studied exon (Table 6). Diversity parameters are presented in (Table 2). Haplotype diversity (h) ranged from 0.6750 to 0.8044 and nucleotide diversity $(\pi)$ from 0.0035 to 0.0043 .

Tajima's selective neutrality test (1983) generated the following results: $D=-0.96266$ for Cape Aglou population, $D=$ -1.42180 for Cape Ghir population, and D $=0.03136$ for Anza population. All tests were not statistically significant $(P>0.10)$.

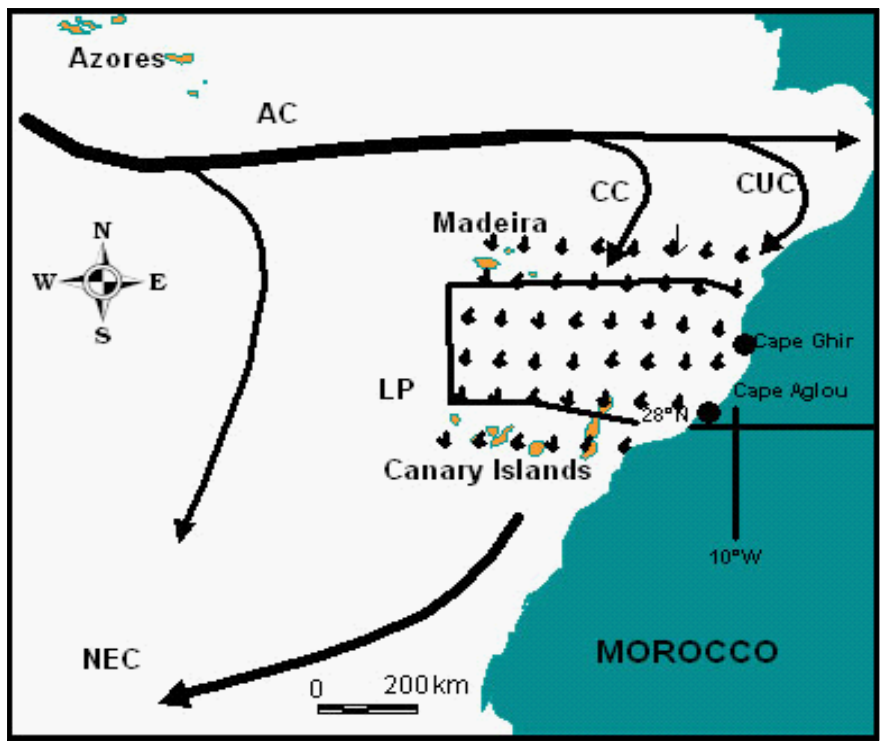

Figure 2. The Canary Current along the Atlantic coast of Morocco (as described by Machín et al. 2006). LP: La Palma, AC: Azores Current, CC: Canary Current, CUC: Canary Upwelling Current, and NEC: North Equatorial Current. 
Table 6. Distribution of non-synonymous substitutions. Four amino acids were changed: Tyrosine (Y) to Serine (S), Valine (V) to Alanine (A), Tyrosine $(\mathrm{Y})$ to Asparagine $(\mathrm{N})$, and Threonine $(\mathrm{T})$ to Lysine $(\mathrm{K})$.

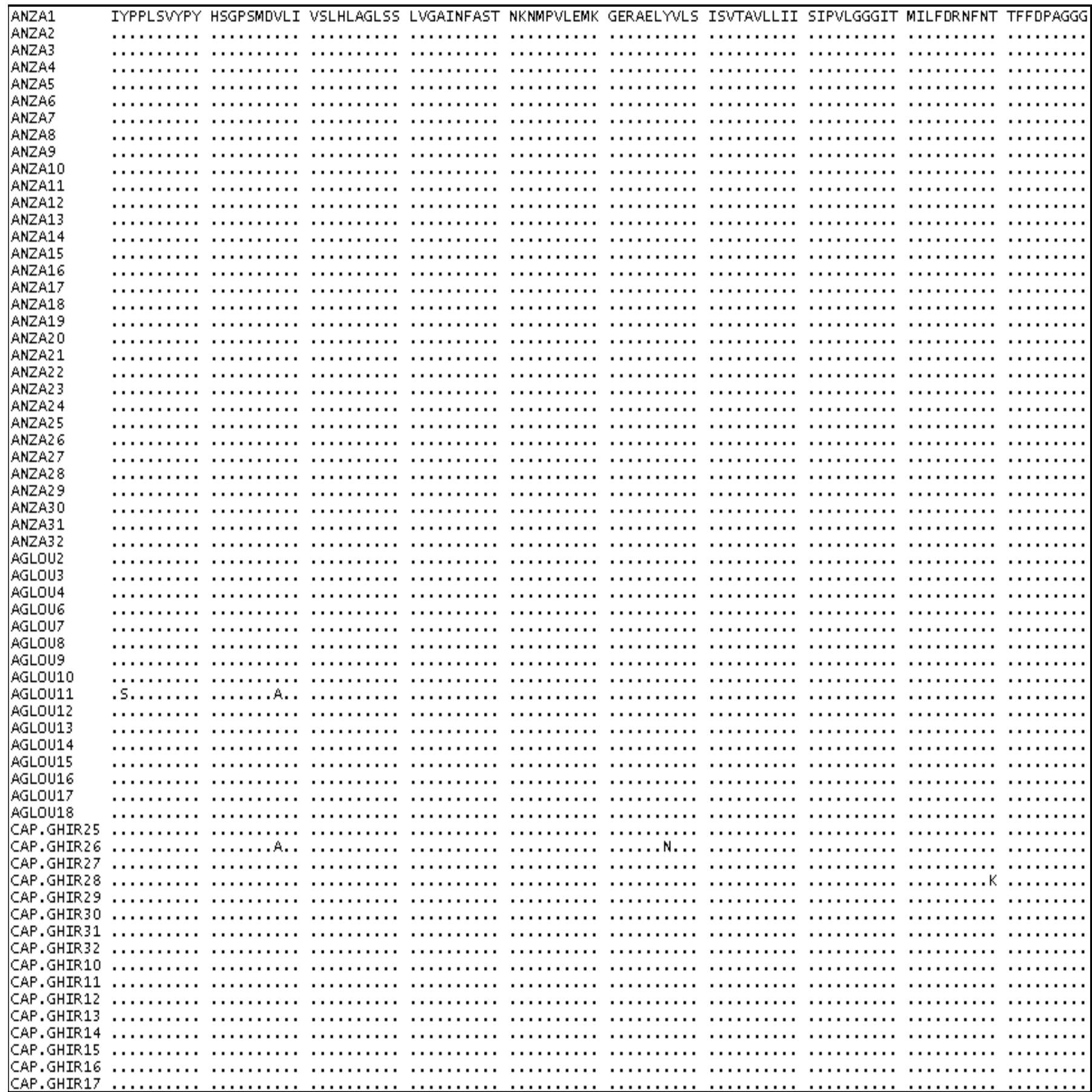

\section{Inter-population Variation}

The mean genetic distance within study sites and for the whole study area, using the Kimura 2-parameters model that takes in consideration transversions and transitions, was estimated as $d$ $=0.4 \%$. The mean genetic distance between Anza and Cape Aglou populations is equal to that between Aglou and Cape Ghir $(0.4 \%)$, and between Anza and Cape Ghir is equal to $0.5 \%$. The coefficient of differentiation is of 0.032 . In (Table 4), the values of pairwise Fst and P-values are shown.
Genetic structure and population differentiation were examined using the Analysis of Molecular Variance method (AMOVA) (Excoffier et al. 2006) and this revealed that $97.17 \%$ of variation exists within populations and only $2.83 \%$ between them (Table 5). The fixation index (Wright 1951) was estimated at the $5 \%$ level as Fst $=0.0283(P$-value $=0.1214)$.

Gene flow appears to be more common between Anza and Cape Aglou populations $(\mathrm{Nm}=88.49)$, weaker between Anza and Cape Ghir $(\mathrm{Nm}=6.86)$, and absent between Cape Aglou and Cape Ghir populations ( $\mathrm{Nm}<0)$. 
The Minimum spanning network showed no distinct clades among the 3 wild populations and the 13 OTUs (Operational Taxonomic Units) (Fig. 1). Four haplotypes were private in Cape Ghir (Hap 12, Hap 3, Hap 10 and Hap 2), one in Cape Aglou (Hap 13) and five in Anza site (Hap 4, Hap 7, Hap 5, Hap 8 and Hap 9). The common ancestor is represented by a central rectangle (Anza1). The rest of haplotypes was shared between two or three populations (Hap 1, 6, and 11 between Anza and Cape Aglou, Hapl and 11 between Anza and Cape Ghir, and between Cape Aglou and Cape Ghir.

\section{Discussion}

\section{The Choice of the Gene COI}

In an early stage, we carried out several tests on the mtDNA hypervariable region. These tests failed to amplify the $d$-loop region, most probably due to polymorphism in the species at the priming sites targeted by the primers we essayed. Indeed, the genome of mussels is considered one of the most complex genomes in the Animal Kingdom. Their mtDNA organization can undergo several genetic events such as Double Uniparental Inheritance (DUI) (Zouros et al. 1992, Garrido-Ramos et al. 1998, Zbawicka et al. 2003, Mizi et al. 2005), masculinization event (Hoeh et al. 1997, Sirna et al. 2007), gene rearrangements, recombination (Hoffmann et al. 1992, Ladoukakis et al. 2001, Mizi et al. 2005, Burzyński 2007 et al. and Venetis et al. 2007), and males heteroplasmy and females homoplasmy (Hoeh et al. 1991, Wenne et al. 1995, Cao et al. 2004). The mtDNA COI gene was chosen as an alternative for two reasons: (i) its fast mode of evolution (Wares et al. 2001, Riginos et al. 2004 and Gérard et al. 2008), and (ii) to our knowledge, the fact that no genetic study has used this gene to survey the Moroccan populations of Mytilus galloprovincialis. The studies undertaken on DNA barcodes, especially focusing on the $\mathrm{COI}$ gene, were very useful and facilitated this population study. In addition to the fact that the $\mathrm{COI}$ gene constitutes the core of a global bio-identification system for animals, it also allows unambiguous identification of more than 200 species and remains thus, the most accessible and practical molecular tool for populations studies (Herbert et al. 2002).

\section{Genetics of Populations}

In population genetics, the distribution of genetic variation between populations and individuals is deduced from the study of their genetic structure. The latter is often under the action of various evolutionary forces like selection, migration, genetic drift and mutation.

According to (Table 5), the intra-population genetic diversity is very high in the three zones (97\%). In spite of the observed mutations, AMOVA failed to reveal a significant difference between the three populations and showed that the essential haplotype variation is essentially due to the intra-population diversity. Mussel mtDNA may also be subject to different selective pressures (Zbawicka et al. 2003 and Riginos et al. 2004). The frequency and strength with which selection shapes patterns of genetic variation is unknown. Whereas all loci should be roughly equally affected by demography and population history, selected loci may exhibit increased or decreased genetic differentiation relative to neutral loci (Cavalli-Sforza 1966 and Riginos et al. 2002). Neutrality results suggested that Cape Ghir and Aglou populations are under the action of a directional and purifying selection since the values of Tajima's test were negative. On the other hand, Anza population might be under the action of balanced and stabilizing selection that favours the extreme individuals on this impacted site. Despite the potential pollutioninduced mutations at Anza site, and according to AMOVA, Fst analysis, and gene flow estimates, it seems that there is a genetic homogeneity across the three sites, despite inter-site distances that can be over $150 \mathrm{~km}$. The observed homogeneity could be explained by the marine Canary currents characterizing this coastal area (Fig. 2).

Many oceanographic and environmental studies have examined these currents, which constitute a natural extension of the main Azores current. Furthermore, (Mittelsstaedt 1991), (Jaziri et al. 2002), (Stevens et al. 2003), and (Machín et al. 2006) confirmed that at Cape Ghir, the Canary current hugging the Atlantic coast changes completely its direction and continues towards the Canary archipelago. This change of direction suddenly cuts and stops the pelagic larval dispersal and, consequently, the gene flow in this region, characterized also by the formation of the Upwelling filaments.

\section{Mediterranean Mussel: Genetics and Impact of Pollution}

Mussels adjust their functions to ordinary environmental changes such as, temperature fluctuations and emersion-related hypoxia and react to various contaminants (Venier et al. 2006). During the sampling phase, we noticed that the phenotype of the mussels is slightly different. Mussels sampled from the impacted area were small and their numbers seem to be depleted. Cape Aglou samples were medium-sized and abundant, and Cape Ghir samples were big and apparently abundant. Also, during the DNA extraction phase, the majority of the tissues of Anza mussels showed spotted patterns and viscous haemolymphs. Could this be considered as a manifestation of the pollution impact at Anza region?

In his evaluation of the Moroccan marine environment, (Berraho 2006) stated that the fundamental ecological parameters like species richness and the abundance have been affected by the high quantities of heavy metals at the pollution epicentres. It were also reported, the dramatic impacts of the discharge by the Jorf Lasfar industrial and phosphate processing complex on the marine fauna (e.g. mussels showing shell deformations). At the genetic level, no significant differentiation between Cape Ghir and Cape Aglou populations was found. However, a shallow significant differentiation is observed between Anza and Cape Ghir populations (Fst $=0.0672$ and $\mathrm{P}$-value $=0.002637$ ). Unless the connectivity factor is taken into consideration, this differentiation might not be explained by marine pollution at Anza region as the 4 non-synonymous substitutions occurred in 3 individuals that lived out of this impacted region. Our results on the whole distribution of the genetic variation among and within 
populations demonstrated the absence of structuring between the three populations (Table 5). The calculation of the global fixation index confirmed this (Fst $=0.02832)$. In a similar study, a lack of genetic structure and likely high gene flow, among Littorina brevicula populations was also found by (Kim et al. 2003) while working on polluted and non polluted sites around the Korean coastlines. According to the Food and Agriculture Organization, only few studies have dealt with the genetic changes potentially associated to marine pollution. Investigations made by (Lavie et al. 1982) and (Hvilsom 1983) on molluscs and crustaceans showed different survival rates of distinct allozymes genotypes to heavy metals pollution. (Fevolden et al. 1986) studied the exposition of Mytilus edulis to low oil contents in Norwegian fjords and did not detect evidence of a genotypic selection. Additionally, (Nevo et al. 1986), while studying pairs of species exposed to marine pollutants, stated that the species having the highest level of genetic diversity had the longest survival potential. Our investigation on mussel's mechanisms and strategies of adaptation to marine pollution, led us to a study conducted by (Duchemin 2007) on marine immunotoxicology. Duchemin's study, carried out on two bivalve species (mussel and oyster), showed that the immune system adopts a seasonal variation in narrow correlation with the function of reproduction (thus, with the genetic function). Moreover, it was demonstrated that females possess a significantly higher immune competence than males during all seasons. So, most likely, through this control of the immune system by sex and reproduction cycle, bivalves manage to somewhat counter the immunotoxic effect of chemical and organic pollutants.

\section{Conclusion and Perspectives}

Mytilus galloprovincialis constitutes a biological resource with ecological and economic interests. Certainly, the species plays an important role for the intertidal communities. For example, with its filtrating capacity of the marine material in suspension, it can influence the dynamics of many coastal systems, and consequently, the local marine biodiversity (Seed 1996). Mussels are also regarded as structural and functional entities because, via their beds along the marine rocky zone, they provide refuges, shelters and habitats for other invertebrates such as polychaetes and amphipods (Peake et al. 1993). The results of the studies cited above are mostly confirmed by our findings. However, for a broader evaluation and assessment of the impact of pollution on mussels' populations living in Agadir bay, or in the other Moroccan coastal regions, supplementary data and records from the monitoring and surveillance of the marine areas' quality, human exploitation and the surrounding marine ecosystems, prove to be necessary. Environmental parameters like temperature, salinity, sites exposure to wave action, sites geography and food availability, also have a great impact on Mytilus galloprovincialis survival and biology (spawning and reproduction periods, growth, filtration rate...etc.), and should be further investigated in this region of concern.

The estimation of genetic variation showed that in spite of the pollution impact, particularly at Anza zone, genetic diversity has not been lost yet, a factor that might enable the mussels living at Agadir bay to survive and cope with the different environmental pressures and stresses. Since mussel farming is nascent in Morocco, we do hope that this preliminary study might add to the valorization of the marine resources and the development of this practice at Agadir bay. For the next phase, we will study male specimen and also will increase our samples to cover more Atlantic and Mediterranean regions, so that we can contribute to a more informed coastal planning in Morocco.

\section{Acknowledgements}

The authors are very grateful to the Institut National de Recherche Halieutique (INRH), Agadir, Morocco, His Royal Highness Prince Sultan Bin Abdul Aziz Al Saud International Foundation for Conservation and Development of Wildlife, Morocco, and Pr. Roman Wenne from the Polish Academy of Sciences. For their technical assistance, we thank, Pr. Hassan Jaziri, Jonathan Gardner, Ann Wood, Gerardo Zardi, and Manuel Manchado. We are indebted to Fatima El Aamri, M. Naoufal Tamsouri, Badiâa lazza, M. Taha Moutaoufik, and Subhash Krishnan either for their assistance in the field or help. Thanks must also go to Pr. Cynthia Riginos, Pr. Wiebe Kooistra, Carlos Fernandes and anonymous referees for their helpful comments on the manuscript. A special thank to M.H Miouz for the inspiration during this study.

\section{References}

Abouabdellah R, Taleb H, Bennouna A, Erler K, Chafik A, Moukrim A (2008) Paralytic shellfish poisoning toxin profile of mussels Perna perna from southern Atlantic coasts of Morocco. Toxicon 51: 780786.

Benomar S, Bouhaimi A, El Hamidi F, Mathieu M, Ouichou A, Moukrim A (2006) Cycle de reproduction de la moule africaine Perna perna (Mollusca, Bivalvia) dans la baie d'Agadir : Impact des rejets d'eaux usées domestiques et industrielles. Biologie \& Santé vol. $6, \mathrm{n}^{\circ} 1$.

Berraho (2006) Evaluation du milieu marin. Rapport de I'Institut National de Recherche Halieutique (INRH). Casablanca. Maroc.

Bouhaimi A, Idhalla M, Kaaya A, Mathieu M, Moukrim A (1999-2000) Etude comparative des moules Perna perna et Mytilus galloprovincialis dans la baie d'Agadir (sites : Cap Ghir et Anza). Haliotis, vol. 29, pp. 27-41.

Burzyński A (2007) Two events are responsible for an insertion in a paternally inherited mitochondrial genome of the mussel Mytilus galloprovincialis. Genetics 175: 959-962.

Cao L, Kenchington E, Zouros E, Rodakis GC (2004) Evidence that the large noncoding sequence is the main control region of maternally and paternally transmitted mitochondrial genomes of the marine mussel (Mytilus spp.). Genetics 167, 835-850.

Cavalli-Sforza L (1966) Population structure and human evolution. Proc. R. Soc. Lond. Ser. B 164:362-379.

Clement M, Posada D, Crandall K.A (2000) TCS: a computer program to estimate gene genealogies. Molecular Ecology 9 (10): 1657-1659.

Daguin C, Borsa P (1999) Genetic characterisation of Mytilus galloprovincialis Lmk. in Northwest Africa using nuclear DNA markers, J. Exp. Mar. Biol. Ecol. 235 : 55-65.

Dardignac-Corbeil MJ (1986) La mytiliculture traditionnelle. Aquaculture, Volume 1: 286-329. Techniques et Documentations, Lavoisier, Paris.

Diethard \& Renz (1983) An optimized freeze-squeeze method for recovery of DNA fragments from agarose gels. Analytical Biochemis- 
try. 132(1): 14-19.

Duchemin M (2007) Validation des outils immunotoxicologiques pour l'étude des effets biologiques des contaminants du milieu marin. Thèse de doctorat. Université de Bretagne Occidentale et Institut Armand Frappier.

Excoffier L, Lavale G, Schneider S (2006) Arlequin ver. 3.1: A Software for Population Genetic Analysis. Genetics and Biometry Laboratory, University of Geneva, Switzerland.

Fevolden SE, Garner SP (1986) Population genetics of Mytlius edulis (L) from Oslofjorden, Norway, in oil-polluted and non oil-polluted water. Sarsia 71: 247-257.

Filatov DA (2002) Proseq: A software for preparation and evolutionary analysis of DNA sequence data sets. Molecular Ecology Notes 2, 621-624.

Folmer O, Black M, Hoeh W, Lutz R, and Vrijenhoek R (1994) DNA primers for amplification of mitochondrial cytochrome $c$ oxidase subunit I from diverse metazoan invertebrates. Mol Mar Biol Biotechnol, Oct 3(5):294-9.

Garrido-Ramos, Stewart MADT, Sutherland BW, Zouros E (1998) The distribution of male-transmitted and female-transmitted mitochondrial DNA types in somatic tissues of blue mussels: implications for the operation of doubly uniparental inheritance of mitochondrial DNA. Genome 41:818-824.

Gérard K, Bierne N, Borsa P, Chenuil A, Féral JP (2008) Pleistocene separation of mitochondrial lineages of Mytilus spp. Mussels from Northern and Southern Hemispheres and strong genetic differentiation among southern populations.. Mol. Phylogen. Evol.

Hebert PDN, Cywinska A, Ball SL, DeWaard JR (2002) Biological identifications through DNA barcodes. The Royal Society.

Hilbish TJ, Mullinax A, Dolven SI, Meyer A, Koehn RK, Rawson PD (2000) Origin of the antitropical distribution pattern in the marine mussels (Mytilus spp.): routes and timing of transequatorial migration. Mar. Biol. 136, 69-77.

Hoeh WR, Blakley KH, Brown WM (1991) Heteroplasmy suggests limited biparental inheritance of Mytilus mitochondrial DNA. Science 251:1488-1490

Hoeh WR, Stewart C, Saavedra BW, Sutherland, Zouros E (1997) Phylogenetic evidence for role-reversals of gender-associated mitochondrial DNA in Mytilus (bivalvia: Mytilidae). Mol. Biol. Evol. 14:959-967

Hoffmann RJ, Boore JL, Brown WM (1992) A novel mitochondrial genome organization for the blue mussel Mytilus edulis. Genetics 131, 397-412.

Hvilsom MM (1983) Copper-induced differential mortality in the mussel Mytilus edulis. Marine Biology 76: 291-295.

Jaziri H, Benazzou T (2002) Différenciation allozymique multilocus des populations de moules Mytilus galloprovincialis Lmk. des côtes marocaines. Multilocus allozyme differentiation of mussel populations Mytilus galloprovincialis Lmk. from Moroccan coasts. C. R. Biologies $325: 1175-1183$.

Jaziri H, Sbabou L (2003) Variabilié morphologique et systématique de la moule méditerranéenne Mytilus galloprovincialis Lmk. (Bivalvia, Mytilidae) au Maroc. Haliotis 32:61-72.

Kaimoussi A, Chafik A, Mouzdahir A, Bakkas S (2001) The impact of industrial pollution on the Jorf Lasfar coastal zone (Morocco, Atlantic Ocean): the mussel as an indicator of metal contamination. C. R. Acad. Sci. Paris, Sciences de la Terre et des planètes/Earth and Planetary Sciences 333 (2001) 337-341.

Kim SJ, Rodriguez-Lanetty M, Song JI (2003) Genetic population structure of Littorina brevicula around Korean waters. Hydrobiologia, 505 1-3: 41-48.

Kimura M (1980) A simple method for estimating evolutionary rate of base substitutions through comparative studies of nucleotide sequences. Journal of Molecular Evolution

16:111-120.

Ladoukakis ED, Zouros E (2001) Direct evidence for homologous recombination in mussel (Mytilus galloprovincialis) mitochondrial DNA. Mol. Biol. Evol. 18(7): $1168-1175$.

Lavie B, Nevo E (1982) Heavy metal selection of phosphoglucose isomerase allozymes in marine gastropods. Marine Biology 71: 17-22.

Librado P and Rozas J (2009) DnaSP v5: A software for comprehensive analysis of DNA polymorphism data. Bioinformatics 25: 1451-1452.

Maanan M (2008) Heavy metal concentrations in marine molluscs from the Moroccan coastal region. Environmental Pollution 153: 176-183.

Machín F, Hernandez-Guerra A, Pelegri JL (2006) Mass Fluxes in the Canary Basin. Progress in Oceanography, Volume 70, Issues 2-4.

McDonald JH, Seed R, Koehn RK (1991) Allozymes and morphometric characters of three species of Mytilus in the Northern and the Southern hemispheres. Marine Biology 111 : 323-333.

Mimouni R, Ait Alla A, Anaijar EM, Finance C, Moukrim A (2002) Impact du rejet des eaux usées sur la qualité microbiologique des plages de la baie d'Agadir (Maroc). Journal européen d'hydrologie. Vol. 33, nol, pp. 115-123.

Mittelstaedt E (1991) The ocean boundary along the NW African coast: circulation and oceanographic properties at the sea surface. Prog. Oceanogr. 26, 307-355.

Mizi A, Zouros E, Moschonas N, Rodakis GC (2005) The complete maternal and paternal mitochondrial genomes of the Mediterranean mussel Mytilus galloprovincialis: Implications of the doubly uniparental inheritance mode of mtDNA. Molecular Biology and Evolution. Vol. 22 no. 4.

Moustaid K, Nasser B, Baudrimont I, Anane R, El Idrissi M, Bouzidi A, Creppy EE (2005) Évaluation comparée de la toxicité des moules (Mytilus galloprovincialis) de deux sites du littoral atlantique marocain sur des souris. C. R. Biologies 328 : 281-289.

Naciri M (1998) Dynamique d'une population de moules, Mytilus galloprovincialis (Lmk.), vivant sur la côte atlantique marocaine. Bulletin de I'Institut Scientifique, Rabat, $n^{\circ} 21$, pp. 43-50.

Nevo, Noy, Lavie, Beiles, Muchtar (1986) Genetic diversity and resistance to marine pollution. Biological Journal of the Linnean Society 29: 139-144.

Peake J, Quinn GP (1993) Temporal variation in species-area curves for invertebrates in clumps of an intertidal mussel. Ecography. 16: 269-277.

Riginos C, Hickerson MJ, Henzler CM, Cunningham CW (2004) Differential patterns of male and female m+DNA exchange across the Atlantic Ocean in the blue mussel, Mytilus edulis. Evolution. 58, 24382451.

Riginos C, Sukhdeo K and Cunningham CW (2002) Evidence for selection at multiple allozyme loci across a mussel hybrid zone. Mol. Biol. Evol. 19(3): 347-351.

Sambrook, Fritsch, Maniatis (1989) Molecular cloning: A laboratory manual (2nd Edition). Cold Spring Harbor Laboratory Press.

Seed R (1996) Patterns of biodiversity in the macro-invertebrate fauna associated with mussel patches on rocky shores. J. Mar. Biol. Ass. UK. 76: 203-210.

Shafee MS (1989) Reproduction of Perna picta (Mollusca: Bivalvia) from the Atlantic coast of Morocco. Marine Ecology Progress Series 53:235-245.

Sirna TM, LoBrutto S, Arculeo M, Mitton JB (2007) A mitochondrial phylogeography of Brachidontes variabilis (Bivalvia: Mytilidae) reveals three cryptic species. J. Zoolog. Syst. Evol. Res. 45 (4), 289-298

Stevens I, Johnson J (2003) A numerical modelling study of upwelling filaments off the NW African coast. Oceanologica Acta, volume 26, 549-564. 
Tajima F (1983) Evolutionary relationship of DNA sequences in finite populations. Genetics 105: 437-460.

Venetis C, Theologidis I, Zouros E, Rodakis GC (2007) A mitochondrial genome with reversed transmission route in the Mediterranean mussel Mytilus galloprovincialis. Gene 406: 79-90.

Venier P, De Pittà C, Pallavicini A, Marsano F, Varotto L, Romualdi C, Dondero F, Viarengo A and Lanfranchi G (2006) Development of mussel mRNA profiling: can gene expression trends reveal coastal water pollution?. Mutation Research/Fundamental \& Molecular Mechanisms of Mutagenesis. 602, 1-2, pp.121-134.

Wares JP, Cunningham CW (2001) Phylogeography and historical ecology of the North Atlantic interdidal. Evolution. 55, 2455-2469.

Wenne R, Skibinski DOF (1995) Mitochondrial DNA heteroplasmy in European populations of the mussel Mytilus trossulus. Mar. Biol. 122, 619-624.
Wood AR, Apte S, MacAvoy ES, Gardner JPA (2007) A molecular phylogeny of the marine mussel genus Perna (Bivalvia: Mytilidae) based on nuclear (ITS1\&2) and mitochondrial (COI) DNA sequences. Molecular Phylogenetics and Evolution 44: 685-698

Wright S (1951) The genetical structure of populations. Ann Eugen 15: 323-354.

Zbawicka M, Skibinski DOF, Wenne R (2003) Doubly uniparental transmission of mitochondrial DNA length variants in the mussel Mytilus trossulus. Mar. Biol. 142, 455-460.

Zbawicka M, Wenne R and Skibinski D.O.F (2003) Mitochondrial DNA variation in populations of the mussel Mytilus trossumus from the Southern Baltic. Hydrobiologia, 499, $\mathrm{N}^{\circ}$ 1-3, pp. 1-12(12).

Zouros E, Freeman KH, Ball AO, Pogson GH (1992) Direct evidence for extensive paternal mitochondrial DNA inheritance in the marine mussel Mytilus. Nature 359:41 2-414. 